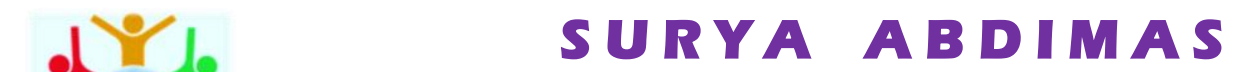

Vol. 5 No. 3 (2021) pp. 280 - 292

Available online at: http://jurnal.umpwr.ac.id/index.php/abdimas/index

p-ISSN: 2580-3492 e-ISSN: $\underline{2581-0162}$

\title{
Penyusunan dan Pelatihan Kerangka Kerja Publikasi Karya Ilmiah Populer untuk Mahasiswa
}

\section{Rizki Pratama $\bowtie$, Abd. Qadir Muslim, Bayu Amengku Praja, Bayu Indra Pratama, Endry Putra}

Universitas Brawijaya

Jl. Mayjen Haryono 169, Lowokwaru - Jl. Veteran, Malang 65145, Jawa Timur, Indonesia

| pratamarizkim@ub.ac.id $\bigotimes$ | DOI : https://doi.org/10.37729/abdimas.v5i3.1280 |

\begin{abstract}
Abstrak
Posisi karya tulis ilmiah yang dipublikasikan oleh mahasiswa sangat penting terutama untuk membekali mahasiswa dengan kemampuan analisis akademik dan juga meningkatkan reputasi akademik Program Studi hingga Universitas akan tetapi muncul berbagai masalah seperti publikasi karya tulis ilmiah terutama karya tulis ilmiah populer yang seringkali tidak memiliki tolak ukur dan panduan yang jelas. Oleh karena itu tujuan program pengabdian masyarakat ini adalah untuk meningkatkan pemahaman mahasiswa tentang publikasi karya ilmiah populer sebagai usaha untuk meningkatan kemampuan akademik dan reputasi program studi melalui sebuah kerangka kerja yang komprehensif. Dalam proses penyusunan kerangka kerja publikasi karya tulis ilmiah populer maka diperlukan tahapan yang sistematik yaitu dimulai dari penyusunan kerangka kerja melalui sebuah buku panduan, melakukan validasi terhadap buku panduan tersebut yang kemudian diperlukan sebuah workshop sebagai sarana edukasi bagi mahasiwa dan hasil akhir buku panduan dievaluasi oleh mahasiswa dan juga dosen sehingga semakin komprehensif. Pada akhirnya dapat disusun sebuah buku panduan sebagai kerangka kerja publikasi karya tulis ilmiah populer untuk mahasiswa yang dapat digunakan untuk kegiatan pelatihan guna meningkatkan pemahaman mahasiswa tentang publikasi karya tulis ilmiah populer.
\end{abstract}

Kata Kunci: Buku panduan, Karya ilmiah populer, Publikasi, Mahasiswa, Pelatihan, Penyusunan (c) (i) (8) This work is licensed under a Creative Commons Attribution-NonCommercial 4.0

\section{Pendahuluan}

Tugas seorang pengajar di perguruan tinggi adalah memberikan layanan pendidikan yang optimal kepada para mahasiswa baik layanan akademik atau pun nonakademik. Customer utama Universitas adalah mahasiswa oleh karena itu semua aktivitas harus berfokus pada pengembangan diri seorang mahasiswa. Keberhasilan pendidikan tinggi adalah ketika mahasiswa yang dididik juga sama berhasilnya. Hal tersebut juga menjadi bukti penting bahwa posisi mahasiswa dalam era saat ini semakin tinggi perannya dalam kehidupan masyarakat dan negara (Hayat \& Zamzami, 2019; Mopangga, 2014; Salam et al., 2017).

Program Studi merupakan ujung tombak dalam melaksanakan kegiatan akademik. Seluruh sistem akreditasi pun menitikberatkan pada kualitas akademik sebuah program studi. Atmosfir akademik dan non-akademik program studi telah menjadi tolak ukur bagi program studi. Berbagai upaya progresif, kreatif dan inovatif harus dilakukan oleh pengelola untuk tetap menjadi program studi yang terdepan baik dalam skala nasional dan global. Akan tetapi dalam rangka untuk terus meningkatkan diri (continuous improvement) diperlukan berbagai usaha untuk meningkatkan kualitas 
akademik ataupun non-akademik terutama untuk pelayanan pendidikan bagi mahasiswa.

Pelayanan akademik mahasiswa harus mampu meningkatkan kemampuan literasi mereka dan memiliki perspektif kritis sebagai produk pendidikan tinggi. Banyak mahasiswa hari ini mampu berdebat akan tetapi kurang mampu menulis. Padahal dua kemampuan tersebut berjalan beriringan sebagai ciri khas mahasiswa era milenial yang anti status quo. Pemahaman mahasiswa dalam tulis-menulis masih dirasa kurang. Seringkali aktivitas tulis-menulis kurang dianggap penting oleh mahasiswa (Ismail \& Elihami, 2019; Kusumawardhani et al., 2012; Sugiarti, Anggraini \& Musaffak, 2015). Padahal prestasi akademik mahasiswa juga ditentukan oleh kemampuan literasi media (Basri, 2012). Sehingga kegiatan penulisan merupakan kegiatan yang penting dan harus dilakukan oleh mahasiswa.

Beberapa program pengabdian masyarakat dengan topik serupa menyarankan kegiatan pelatihan sebagai cara untuk meningkatkan kemampuan menulis (Purwahida, Pratiwi, Arum, 2009; Tumanggor, 2014; P. D. Sasongko \& Hidayatul R., 2021). Akan tetapi perlu juga dilakukan usaha sistematis dalam menyusun bahan pelatihan yang lebih komprehensif melalui buku panduan serta proses pasca pelatihan melalui kegiatan pendampingan bagi para mahasiswa.

Oleh karena itu tujuan yang akan dicapai dalam pengabdian masyarakat ini adalah untuk mengatasi permasalahan kurangnya pemahaman mahasiswa Administrasi Publik Fakultas Ilmu Administrasi Universitas Brawijaya tentang bagaimana melakukan publikasi artikel karya ilmiah populer sebagai usaha untuk meningkatkan kemampuan akademik mahasiswa.

\section{Metode}

Metode pelaksanaan terdiri dari dua tahapan besar yaitu identitikasi isu dan rancangan kegiatan pemecahan isu. Identifikasi isu terdiri dari menjelaskan deskripsi isu, mencari sumber isu dan kemudian melakukan analisis dampak, jika isu tersebut gagal untuk diperbaiki. Sedangkan kegiatan pemecahan isu merupakan perancangan kegiatan untuk menyelesaikan isu-isu tersebut. Dalam tahapan identifikasi dilakukan analisis sebagai berikut:

\subsection{Deskripsi Isu}

Ditingkat program studi, masih terus diupayakan untuk meningkatkan kemampuan akademik mahasiswa dengan berbagai cara. Salah satu hal yang seharusnya menjadi tolak ukur adalah publikasi mahasiswa dalam bentuk artikel karya ilmiah populer seperti opini di media masa baik cetak maupun online. Publikasi adalah kunci dalam dunia akademik di berbagai level, tulisan-tulisan apapun yang diproduksi oleh mahasiwa sudah seharusnya menjadi citra mahasiswa yang mewarnai dunia pendidikan tinggi. Muncul istilah publish or perish untuk menunjukkan pentingnya publikasi yang artinya ketika tidak melakukan publikasi maka akan hanya ada kebinasaan atau kematian dalam dunia akademik.

Berbagai Universitas di Indonesia juga memberikan insentif yang cukup besar bagi mahasiswa ketika tulisan mereka mampu menembus media masa lokal, nasional, dan internasional seperti yang dilakukan Universitas Hasanuddin dan Universitas Padjajaran selama ini. Ramainya insentif untuk publikasi mahasiswa menunjukkan 
bahwa publikasi memainkan peran kunci dalam dunia pendidikan tinggi yang secara langsung membuat dampak kepada kemampuan literasi mahasiswa. Berbagai contoh tersebut membuat justifikasi bahwa publikasi mahasiswa artikel opini media masa harus segera digalakkan dalam Lingkungan Program Studi Administrasi Publik Fakultas Ilmu Administrasi Universitas Brawijaya. Sehingga diperlukan kerangka kerja yang mudah dipahami oleh mahasiswa guna melejitkan kinerja akademik mereka terutama pada level pemahaman bagaimana tata cara melakukan publikasi artikel karya ilmiah populer.

\subsection{Sumber Isu}

Isu ini berdasarkan pengalaman dan kejadian nyata ketika mengajar bahwa mahasiswa banyak yang memiliki keaktifkan dalam mengungkapkan pendapat akan tetapi belum dapat menuliskan menjadi sebuah artikel yang dikonsumsi untuk kalangan yang lebih luas. Selain itu juga muncul pertanyaan-pertanyaan dari mahasiswa tentang prosedur untuk dapat menembus berbagai kolom opini media masa. Mahasiswa juga belum banyak memahami soal manfaat menulis artikel seperti untuk meningkatkan kemampuan akademik, kepuasan pribadi ketika artikel dibaca orang banyak serta manfaat finansial.

\subsection{Analisis Dampak}

Permasalahan ini dapat membawa entitas program studi sulit untuk mencetak peserta didik berkemampuan akademik dan/atau professional yang bermutu serta berkepribadian/berjiwa entrepreneur. Pada dasarnya kemampuan akademik mahasiswa tidak hanya dilihat dari indeks prestasi kumulatif (IPK) saja akan tetapi juga dapat dilihat dari kemampuan menulis mahasiswa sehingga jika mahasiswa tidak pandai menulis maka akan menurunkan kualitas akademik mereka. Tulisan opini juga dapat menunjukkan bahwa institusi pendidikan tengah ikut serta mengedukasi masyarakat luas bukan hanya masyarakat internal. Selain itu pada sistem akreditasi program studi (APS) 4.0 bahkan juga harus diwajibkan adanya publikasi mahasiswa berupa artikel opini media masa. Tentu hal tersebut akan menyebabkan memburuknya reputasi akademik program studi jika tidak ada publikasi mahasiswa yang pada akhirnya membuat daya saing lulusan akan menurun. Penurunan daya saing lulusan akan berakibat fatal bagi institusi maupun lulusan Program Studi.

Berdasarkan isu tersebut di atas maka rencana kegiatan dan output yang akan dilaksanakan dalam kegiatan pengabdian masyarakat terdiri dari empat kegiatan utama yaitu pertama, menyusun kerangka kerja yang akan menghasilkan buku panduan, kedua, melakukan validasi kerangka kerja melalui revisi buku panduan dan melakukan praktik secara mandiri berdasarkan buku panduan, ketiga, menyelenggarakan workshop kerangka kerja untuk mahasiswa dan melakukan evaluasi, serta keempat, evaluasi kerangka kerja baik oleh mahasiswa maupun dosen seperti Tabel 1. 
Tabel 1. Kegiatan dan output kegiatan

\begin{tabular}{cll}
\hline No & \multicolumn{1}{c}{ Kegiatan } & \multicolumn{1}{c}{ Output } \\
\hline 1 & Menyusun Kerangka Kerja & Buku Panduan \\
2 & Memvalidasi Kerangka Kerja & $\begin{array}{l}\text { Revisi Buku Panduan dan Hasil } \\
\text { Praktik Buku Panduan } \\
\text { Pelaksanaan Workshop dan Evaluasi }\end{array}$ \\
3 & $\begin{array}{l}\text { Pelatihan melalui Workshop } \\
\text { Kerangka Kerja untuk } \\
\text { Mahasiswa }\end{array}$ & \\
Evaluasi Kerangka Kerja & $\begin{array}{l}\text { Evaluasi Kerangka Kerja Secara } \\
\text { Keseluruhan Baik dari Mahasiswa } \\
\text { maupun Dosen }\end{array}$ \\
\hline
\end{tabular}

\section{Hasil dan Pembahasan}

\subsection{Menyusun Kerangka Kerja}

Kerangka kerja yang dibentuk adalah berupa sebuah buku panduan. Untuk membuat sebuah buku panduan yang komprehensif maka hal yang harus dilakukan adalah mengumpulkan berbagai sumber referensi yang komprehensif pula. Oleh karena itu seluruh sumber bacaan buku digital maupun fisik harus dikumpulkan dan dipelajari secara seksama. Dalam tahapan kegiatan ini banyak digunakan buku digital/e-book karena kemudahan akses dan mudah untuk melakukan check dan re-check atas kontennya.

Pasca mengumpulkan bahan referensi tentu harus dilakukan review satu per satu atas bahan referensi yang akan digunakan, memilah mana yang penting dan tidak terutama menyusun argumen penting yang ada dalam referensi sehingga dapat dimasukkan dalam buku. Harus muncul keputusan tentang mana referensi yang layak dan yang tidak dan melakukan resume agar hasil buku memiliki kualitas yang diharapkan misalkan salah satunya adalah hanya menggunakan referensi terbitan tahun 2000an keatas agar memiliki aspek kebaruan (Tabel 2).

Tabel 2. Review referensi buku panduan

\begin{tabular}{|c|c|c|}
\hline No. & Sumber & Kutipan Penting \\
\hline 1 & (Pratama, 2017) & $\begin{array}{l}\text { Narasi Negara-Negara kesejahteraan di Benua Eropa } \\
\text { dipertunjukkan dengan sangat menarik oleh Michael Moore } \\
\text { dalam karya film Where to Invade Next (2015). }\end{array}$ \\
\hline 2 & (Cheeney, 2001) & $\begin{array}{l}\text { Creative nonfiction tells a story using facts, but uses many of the } \\
\text { techniques of fiction for its compelling qualities and emotional } \\
\text { vibrancy. Creative nonfiction doesn't just report facts, it delivers } \\
\text { facts in ways that move the reader toward a deeper } \\
\text { understanding of a topic. }\end{array}$ \\
\hline 3 & (Uco, 2015) & $\begin{array}{l}\text { How to Write a Thesis (2015) sebenarnya menggunakan } \\
\text { pemilihan topik untuk tulisan tesis milik Umberto Uco akan } \\
\text { tetapi dalam buku panduan ini hanya diambil } 4 \text { konsep } \\
\text { menurut Uco yang sesuai dengan kebutuhan untuk penulisan } \\
\text { artikel. }\end{array}$ \\
\hline
\end{tabular}


$4 \quad$ (Cresswell, 2017; Patton, 2009)

asi langsung. Observasi ini berarti kita mendapatkan ide melalui tindakan kita secara langsung pada sebuah objek dari fenomena tertentu seperti berupa wawancara, pengamatan, keterlibatan langsung pada suatu masalah. Misalkan kita tengah melakukan pengamatan pada perilaku pelanggaran lalu lintas di lokasi tertentu, kemudian melakukan wawancara pada para pengendara dan kemudian ikut bergabung pada komunitas sadar lalu lintas. Observasi tidak langsung. Observasi ini berarti kita mendapatkan ide melalui aktivitas kita yang tidak terlibat secara langsung dengan objek kita seperti membaca artikel koran, laporan penelitian milik orang lain dan membaca buku tentang fenomena tertentu.

5 (Whitaker, 2010)

Pertama, apa yang perlu kita dapatkan dari catatan hasil observasi: Latar belakang informasi dari ide tulisan kita. Misalkan anda akan menulis tentang kemiskinan di Indonesia tentu kita perlu memeriksa sejarah latar belakang kemiskinan di Indonesia terlebih dahulu. Argumen dan penjelasan yang mendukung atau menolak ide kita. Misalkan kita mendapatkan ide dasar bahwa kemiskinan datang dari kebijakan pemerintah yang tidak pro rakyat kecil, maka kita harus mencari argumen dan penjelasan yang mendukung ide kita tersebut dan mencari kritik atas ide tersebut guna menemukan perbaikan ide. Dan yang paling dasar adalah kita harus menemukan fakta, contoh nyata, opini pakar dan dukungan detil-detil lainnya dalam topik tersebut.

6 (Sword, 2012) Resep CARS (Creating Research's Space) John Swales (dalam Sword, 2012) dapat dilakukan 4 tahapan utama untuk menelurkan ide: Tentukan area/topik penelitian. Rangkum penelitian terdahulu.Tunjukkan bahwa penelitian terdahulu tidak lengkap.Rubah gap ke dalam ruang penelitian untuk tulisan saat ini.

7 (Geertz, 2000) Thick description (deskripsi tebal) biasanya hasil sebuah pertanyaan adalah sebuah karakter, klasifikasi, golongan, pola tertentu dari fenomena misalnya penelitian Geertz tentang masyarakat Jawa yang terdiri dari priyayi, santri dan abangan.

8 (Lieberman \& Penggambarkan tebal dari kemiskinan di Amerika Selatan yang Lewis, 1970) mirip seperti Novel akan tetapi tetap akademis.

(Lund, 2014) Jawabannya dalam ilmu sosial akan selalu tergantung pada kondisi tertentu dengan limitasi tertentu atau sangat tergantung pada konteks di mana data diambil

9 (Popper, 2005) induktif adalah singular statement (khusus) ke universal statement (umum) sedangkan deduktif adalah universal statement ke singular statatement. 
Setelah bahan referensi dan hasil diskusi dikumpulkan maka proses penulis buku panduan dimulai. Buku panduan ditulis dengan sistematika yang menjadi kerangka kerja utama yaitu inisiasi, implementasi dan evaluasi. Buku ini ditulis dari ketiadaan karena belum ada buku panduan yang tertulis rapi di institusi sehingga penting untuk segera diberikan kepada mahasiswa sehingga mahasiwa dapat segera untuk menulis untuk meningkatkan kemampuan akademik mereka. Bukti kegiatan dari tahapan ini adalah dokumen buku panduan (Gambar 1) dan link download buku panduan yang dapat diakses melalui: https://s.id/BukuPanduanPublikasiKaryaImiahPopuler

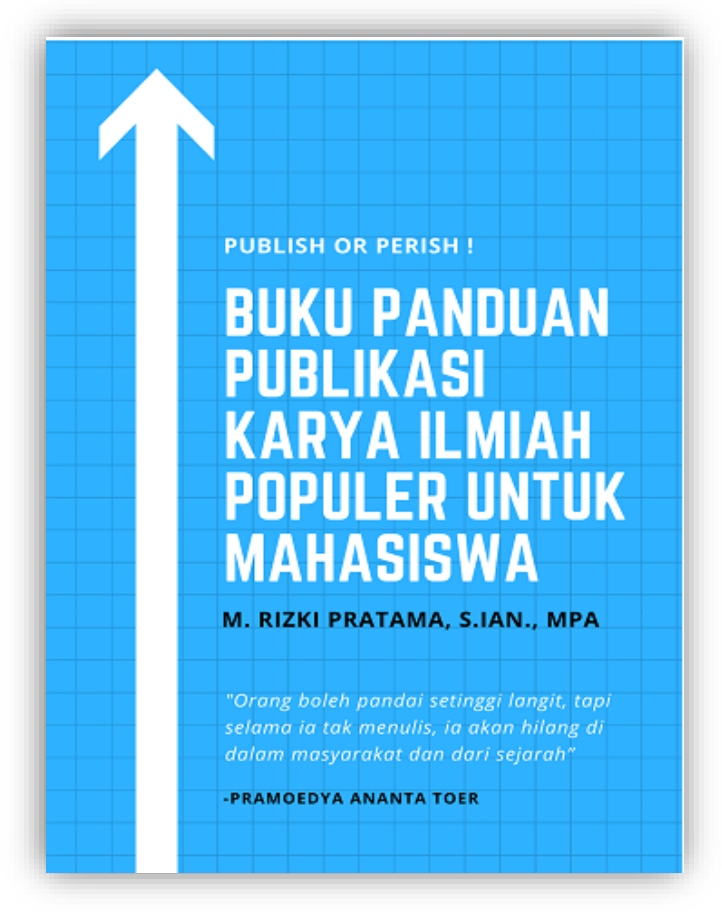

Gambar 1. Cover Buku Panduan

\subsection{Memvalidasi Kerangka Kerja}

Dalam melakukan validasi kerangka kerja agar hasil kerangka kerja komprehensif sebelum dilakukan uji coba maka diperlukan review kepada ahli untuk di-review. Terbentuknya draf buku panduan tersebut harus mendapatkan masukan kembali dari ahlinya. Oleh karena itu diperlukan review dari para dosen yang berpengalaman dalam dunia tulis menulis di media masa. Setelah mendapatkan hasil review maka harus dilakukan perbaikan sesuai masukan dari para reviewer sehingga draf menjadi semakin baik dan siap untuk diterbitkan. Selain itu untuk memastikan kualitas tulisan maka sebenarnya tulisan dalam jenis apapun yang akan diterbitkan dipastikan akan melewati tahapan cek kadar plagiasi baik dengan cara manual melalui screening pakar ataupun menggunakan aplikasi cek plagiarisme. Dengan mengetahui kadar plagiasi maka sebagai seorang akademisi dapat terlihat nilai kejujurannya yaitu tidak mengambil hasil karya orang lain tanpa prosedur yang sesuai dengan standar akademik. Dalam tahapan ini dilakukan cek plagiasi menggunakan aplikasi berbayar sehingga lebih handal untuk melihat kadar plagiasinya. Setelah melakukan pengecekan melalui aplikasi ternyata buku panduan tidak melewati batas kadar plagiarisme yaitu kurang dari 5\% sehingga dapat dikatakan minim dari tindakan plagiasi seperti Gambar 2. 


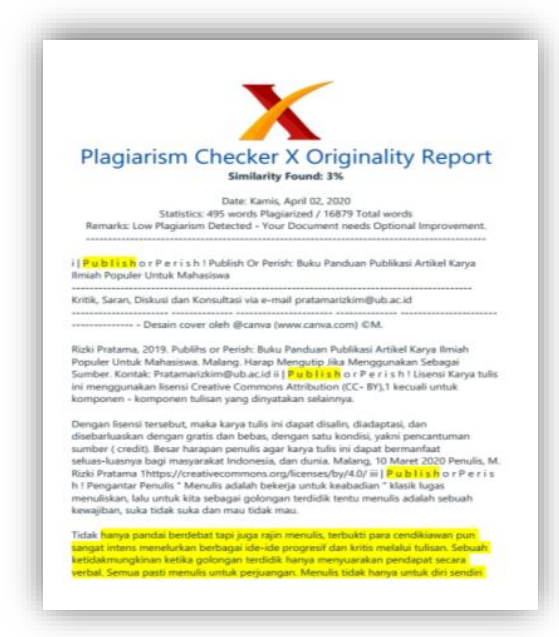

Gambar 2. Hasil cek plagiasi dengan Plagiarism Checker X

Buku yang telah cek plagiasi dan diunggah harus diujicoba dulu prosesnya atau setidaknya penyusun buku panduan harus memiliki kredibilitas untuk membuktikan bahwa memiliki kompetensi menulis kepada para mahasiswa agar dipercaya oleh mahasiswa. Oleh karena itu ditulislah sebuah opini untuk media masa dengan teknikteknik yang ada di buku. Meskipun membutuhkan waktu yang cukup lama untuk mendapatkan pemberitahuan penerimaan naskah pada akhirnya tulisan dapat terbit tepat pada waktunya sehingga dapat diperlihatkan kepada mahasiswa sebelum agenda workshop dimulai seperti ditunjukkan pada Gambar 3.

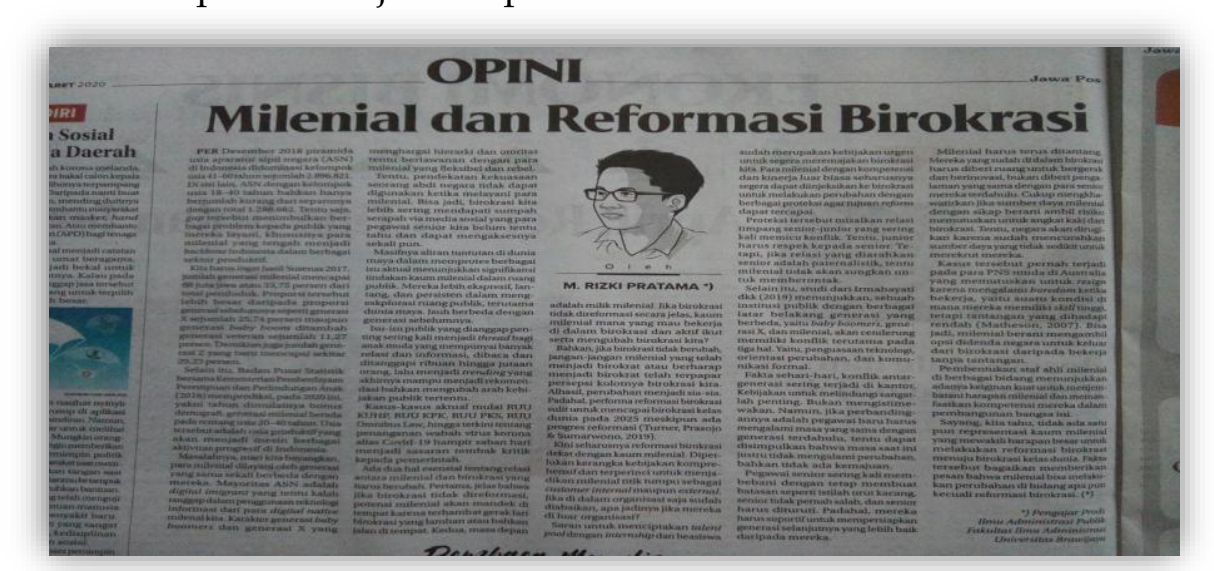

Gambar 3. Hasil submisi dan publikasi karya tulis ilmiah populer

\subsection{Pelatihan melalui Workshop Kerangka Kerja untuk Mahasiswa}

Kegiatan pelatihan workshop dimulai dengan membuka seluasnya-luasnya pendaftaran mahasiswa agar seluruh mahasiswa dapat berpartisipasi. Invitasi disebarkan melalui grup-grup angkatan mahasiswa dan ketua kelas per mata kuliah. Selain itu Materi juga harus disiapkan secara cermat dan teliti di mana harus menyesuaikan dengan buku panduan. Oleh karena itu materi harus ditulis secara sistematis sesuai dengan urutan yaitu pertama, membuat rangkuman materi dari buku, kedua, baru kemudian membuat slide presentasi, ketiga, membuat urutan pernyataan untuk kuliah online yang diberikan nomor angka yang urut. 
Pelatihan melalui workshop ini dilakukan dengan tiga tahapan yaitu pertama, membentuk grup media sosial peserta agar peserta membaca materi terlebih dahulu, kedua, menyelenggarakan pelatihan secara daring agar peserta mendapatkan pengalaman belajar, dan yang ketiga, memberikan pendampingan kepada mahasiswa yang memiliki minat serius untuk melakukan publikasi karya ilmiah populer ke media massa.

Dalam grup media sosial peserta sebelum pelatihan daring dimulai maka seluruh bahan-bahan sudah diberikan dengan rinci mulai dari buku panduan sendiri, slide materi hingga rangkuman buku panduan. Pada saat pelatihan daring materi lebih banyak berfokus pada contoh-contoh penulisan karya ilmiah populer terutama yang telah dilakukan oleh para dosen termasuk memberikan motivasi kepada mahasiswa bahwa menulis dapat meningkatkan kemampuan akademis sekaligus mendapatkan insentif dari media massa yang bervariasi kuantitasnya. Selain itu pasca pelatihan diberikan ruang lebih kepada mahasiswa yang benar-benar memiliki minat tinggi untuk dapat bergabung dalam pendampingan sehingga tulisan mahasiswa dapat menjadi lebih bermutu dan memiliki peluang lebih besar untuk diterbitkan. Arsip pelatihan dapat dilihat pada Gambar 4.
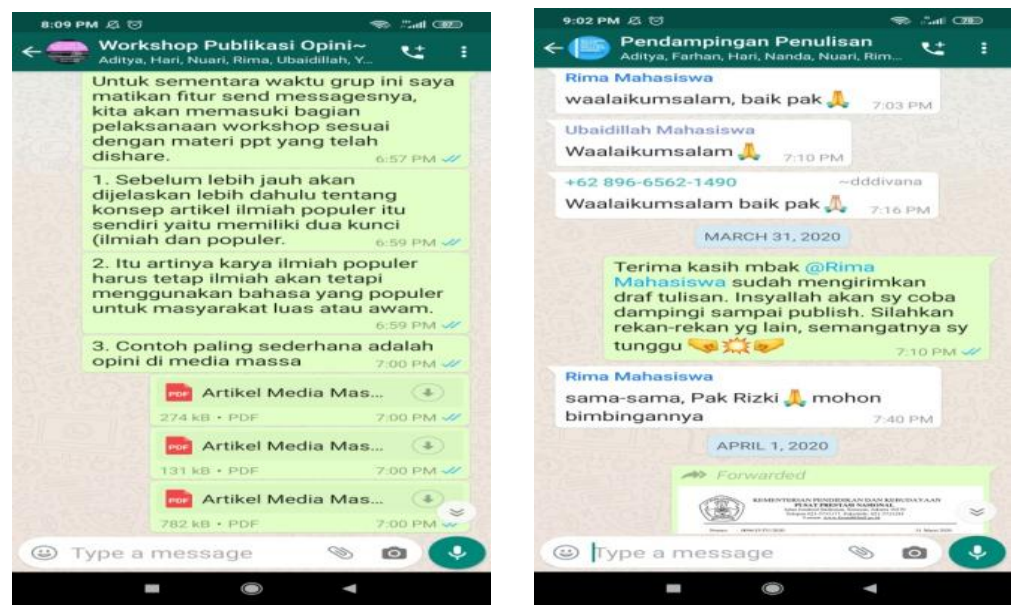

Gambar 4. Arsip pelatihan dan pendampingan mahasiswa

Untuk mengetahui hasil dari workshop perlu dilakukan riset kecil untuk evaluasi sebelum dan sesudah workshop sehingga dapat diketahui apakah anda peningkatan pemahaman mahasiswa terhadap proses publikasi artikel karya ilmiah populer. Untuk merekap, menganalisis serta menarik kesimpulan maka diperlukan akunabilitas setiap prosesnya terutama data isian responden yang akan direkap dan dianalisis agar sesuai dengan data mentahnya tanpa ada pengurangan dan kelebihan sehingga data yang diperoleh dan ditafsirkan merupakan data yang jujur apa adanya yang sesuai dengan standar akademik. Hasil pre-test dan post-test menunjukkan dinamika yang menarik yaitu terjadinya peningkatan pemahaman mahasiswa tentang prosedur publikasi karya tulis ilmiah populer akan tetapi justru terjadi penurunan minat mahasiswa pasca mengikuti workshop. Hal tersebut dimungkinkan karena muncul anggapan tentang kompleksitas dalam proses publikasi ilmiah populer seperti proses penulisan karya yang cukup melelahkan dan menunggu proses publikasi yang cukup panjang (Tabel 3). 
Tabel 3. Hasil Pre-Test dan Post-Test

\begin{tabular}{|c|c|c|c|c|}
\hline No. & Pertanyaan & Pre Test & Post Test & Keterangan \\
\hline 1 & $\begin{array}{l}\text { Pengetahuan } \\
\text { Prosedur } \\
\text { Publikasi } \\
\text { Karya Ilmiah } \\
\text { Populer }\end{array}$ & $\begin{array}{l}84.8 \% \text { responden } \\
\text { tidak mengetahui } \\
\text { prosedur. Responden } \\
\text { yang mengetahui } \\
\text { sebesar } 15.2 \% .\end{array}$ & $\begin{array}{l}100 \% \text { responden } \\
\text { menjawab } \\
\text { memahami. }\end{array}$ & $\begin{array}{l}\text { Meningkatnya } \\
\text { Pemahaman } \\
\text { Pasca } \\
\text { Workshop }\end{array}$ \\
\hline 2 & $\begin{array}{l}\text { Minat } \\
\text { Publikasi } \\
\text { Karya Ilmiah } \\
\text { Populer }\end{array}$ & $\begin{array}{l}84.8 \% \text { responden } \\
\text { berminat. Responden } \\
\text { yang menjawab tidak } \\
15.2 \% \text {. }\end{array}$ & $\begin{array}{l}80.8 \% . \\
\text { Sedangkan } \\
\text { responden yang } \\
\text { menjawab tidak } \\
\text { adalah sebesar } \\
19.4 \% .\end{array}$ & $\begin{array}{l}\text { Menurunyaa } \\
\text { Minat Pasca } \\
\text { Workshop }\end{array}$ \\
\hline
\end{tabular}

\subsection{Evaluasi Kerangka Kerja}

Untuk mengetahui hasil dari kerangka kerja maka dilakukan sebuah evaluasi sebagai tahapan penting sehingga dapat diketahui apakah ada peningkatan pemahaman mahasiswa terhadap proses publikasi artikel karya ilmiah populer. Oleh karena itu disusunlah sebuah form evaluasi dari tiga hal penting yaitu form evaluasi buku oleh mahasiswa, form evaluasi buku oleh mahasiswa dan form evaluasi kualitatif kerangka kerja oleh mahasiswa. Untuk mendapatkan bahan evaluasi tentu membutuhkan responden untuk mengisi kuesioner. Oleh karena itu mahasiswa sebagai objek utama kerangka kerja ini menjadi responden utama. Selain itu juga ada para dosen sebagai peer review dalam memberikan pendapat untuk kedua buku. Seluruhnya tidak dibedabedakan sehingga data dapat dipertanggungjawabkan kebenarannya. Untuk merekap, menganalisis serta menarik kesimpulan maka diperlukan akuntabilitas dalam setiap prosesnya terutama data isian responden yang akan direkap dan dianalisis agar sesuai dengan data mentahnya tanpa ada pengurangan dan kelebihan sehingga data yang diperoleh dan ditafsirkan merupakan data yang jujur apa adanya yang sesuai dengan standar akademik.

Hasil evaluasi mahasiswa tentang buku panduan publikasi artikel karya ilmiah populer (jumlah responden 29) menunjukkan tiga hal penting yaitu pertama, mayoritas mahasiswa menganggap bahwa isi buku panduan sangat membantu untuk meningkatkan pemahaman terhadap proses publikasi karya tulis ilmiah populer, kedua, mayoritas mahasiswa mengungkapkan bahwa bahasa dalam buku telah menggunakan bahasa yang sangat mudah dipahami, dan ketiga, mayoritas mahasiswa menjawab bahwa instruksi/tips dalam buku panduan mudah untuk dipahami. Hasil evaluasi kerja mahasiswa dapat disajikan pada Tabel 4. 
Tabel 4. Hasil evaluasi kerangka kerja oleh mahasiswa

\begin{tabular}{|c|c|c|}
\hline No. & Pertanyaan & Hasil \\
\hline 1 & $\begin{array}{l}\text { Isi Buku } \\
\text { Panduan }\end{array}$ & $\begin{array}{l}\text { Berdasarkan jawaban responden mengatakan bahwa isi } \\
\text { buku panduan sangat membantu untuk meningkatkan } \\
\text { pemahaman mahasiswa terhadap proses publikasi karya } \\
\text { ilmiah populer yaitu sebesar } 75,9 \% \text {. Sedangkan sisanya } \\
24,1 \% \text { menjawab isi buku cukup membantu mahasiswa. }\end{array}$ \\
\hline 2 & $\begin{array}{l}\text { Bahasa Buku } \\
\text { Panduan }\end{array}$ & $\begin{array}{l}\text { Berdasarkan jawaban responden dapat dideskripsikan } \\
\text { bahwa bahasa yang digunakan sangat mudah dipahami } \\
\text { mahasiswa yaitu sebesar } 58,6 \% \text {. Sedangkan yang menjawab } \\
\text { cukup mudah sebesar } 34,5 \% \text {. Selain itu responden yang } \\
\text { menjawab kurang mudah yaitu sebesar } 6,9 \% \text {. }\end{array}$ \\
\hline 3 & $\begin{array}{l}\text { Instruksi/Tips } \\
\text { Buku Panduan }\end{array}$ & $\begin{array}{l}\text { Berdasarkan hasil pengisian kuesioner dapat diperlihatkan } \\
\text { bahwa responden yang menjawab bahwa instruksi/tips di } \\
\text { dalam buku dapat dengan mudah dipahami mahasiswa } \\
\text { adalah sebesar } 72,4 \% \text {. Sedangkan yang menjawab cukup } \\
\text { mudah adalah } 27,6 \% \text {. }\end{array}$ \\
\hline
\end{tabular}

Hasil evaluasi dosen tentang buku panduan publikasi artikel karya ilmiah populer (jumlah responden 19) juga menunjukkan tiga hal penting yaitu pertama, mayoritas dosen menganggap bahwa isi buku panduan sangat membantu untuk meningkatkan pemahaman terhadap proses publikasi karya tulis ilmiah poupler, kedua, mayoritas dosen mengungkapkan bahwa bahasa dalam buku telah menggunakan bahasa yang sangat mudah dipahami, dan ketiga, mayoritas dosen menjawab bahwa instruksi/tips dalam buku panduan mudah untuk dipahami, yang dapat ditunjukkn pada Tabel 5 .

Tabel 5. hasil evaluasi kerangka kerja oleh dosen

\begin{tabular}{|c|c|c|}
\hline No. & Pertanyaan & Hasil \\
\hline 1 & $\begin{array}{l}\text { Isi Buku } \\
\text { Panduan }\end{array}$ & $\begin{array}{l}\text { Berdasarkan jawaban responden mengatakan bahwa isi buku } \\
\text { panduan sangat membantu untuk meningkatkan pemahaman } \\
\text { mahasiswa terhadap proses publikasi karya ilmiah populer } \\
\text { yaitu sebesar } 94,7 \% \text {. Sedangkan sisanya } 5,3 \% \text { menjawab isi } \\
\text { buku cukup membantu mahasiswa. }\end{array}$ \\
\hline 2 & $\begin{array}{l}\text { Bahasa Buku } \\
\text { Panduan }\end{array}$ & $\begin{array}{l}\text { Berdasarkan jawaban responden dapat dideskripsikan bahwa } \\
\text { bahasa yang digunakan sangat mudah dipahami mahasiswa } \\
\text { yaitu sebesar } 68,4 \% \text {. Sedangkan yang menjawab cukup mudah } \\
\text { sebesar } 26,3 \% \text {. Selain itu responden yang menjawab kurang } \\
\text { mudah yaitu sebesar } 7,3 \% \text {. }\end{array}$ \\
\hline 3 & $\begin{array}{l}\text { Instruksi/Tips } \\
\text { Buku } \\
\text { Panduan }\end{array}$ & $\begin{array}{l}\text { Berdasarkan hasil pengisian kuesioner dapat diperlihatkan } \\
\text { bahwa responden yang menjawab bahwa instruksi/tips di } \\
\text { dalam buku dapat dengan mudah dipahami mahasiswa } \\
\text { adalah sebesar } 73,7 \% \text {. Sedangkan yang menjawab cukup } \\
\text { mudah adalah } 26,3 \% \text {. }\end{array}$ \\
\hline
\end{tabular}


Selain itu juga dilakukan evaluasi kualitatif berdasarkan pengalaman mahasiswa selama proses workshop dan melakukan praktik secara mandiri dengan mengirimkan artikel ke media massa, setidaknya muncul beberapa kata kunci terkait manfaat dari kegiatan ini yaitu: a) Pengembangan diri dengan pengetahuan baru dari dunia menulis; b) Peningkatan skill menulis dari buku panduan; c) Mendapatkan ide menulis dari buku panduan; d) Mendapatkan pengarahan dan pendampingan menulis; e) Mendapatkan keberanian untuk mengirim artikel ke media massa. Oleh karena itu berdasarkan evaluasi maka kerangka kerja publikasi karya tulis ilmiah populer melalui buku panduan telah layak untuk menjadi salah satu sumber panduan untuk meningkatkan kemampuan akademik mahasiswa dalam menulis karya tulis ilmiah populer.

\section{Kesimpulan}

Penyusunan dan pelatihan kerangka kerja publikasi karya ilmiah populer untuk mahasiswa telah memberikan pemahaman kepada mahasiswa tentang berbagai proses publikasi yang dapat mahasiswa praktikkan untuk meningkatkan kemampuan akademik. Buku panduan publikasi telah memberikan pengetahuan menulis artikel karya ilmiah populer hingga pengiriman naskah. Berbagai evaluasi selama pelaksanaan workshop dan hasil jadi buku panduan juga memiliki hasil yang positif sehingga buku panduan yang menjadi kerangka kerja layak untuk dipublikasikan secara luas. Selain itu penyusunan kerangka kerja ini masih harus terus disempurnakan terutama mencapai tujuan yang tidak hanya pemahaman mahasiswa saja akan tetapi sampai kepada kemampuan mahasiswa untuk menulis. Oleh karena masih diperlukan banyak kegiatan untuk menyempurnakan seperti pelatihan dengan tatap muka sehingga dapat dilakukan praktik bersama ketika pandemi telah berakhir. Selain itu ke depannya diharapkan publikasi artikel karya ilmiah populer dapat terintegrasi dengan penugasan mahasiswa sehingga menjadi bagian dari rubrik penilaian tugas mahasiswa.

\section{Acknowledgement}

Tim pengabdian masyarakat mengucapakan terima kasih kepada pemerintah desa dan masyarakat desa Pasarsenen yang telah bersedia menjadi mitra dalam kegiatan pengabdian ini. Ucapan terima kasih juga ditujukan kepada LPPM Universitas Muhammadiyah Purworejo yang telah mengizinkan kegiatan ini dilaksanakan serta menyediakan media publikasi artikel hasil pengabdian ini.

\section{Daftar Pustaka}

Basri, S. (2012). Prestasi akademik ditinjau dari kemampuan literasi media. Jurnal Dakwah, XIII(1).

Cheeney, T. A. R. (2001). Writing Creative Nonfiction Fiction Techniques for Crafting Great Nonfiction. Speed Press.

Cresswell, J. W. (2017). Research Design Pendekatan Kualitatif, Kuantitatif, dan Mixed Edisi ketiga. In Yogyakarta: Pustaka Pelajar. Pustaka Pelajar. 
Geertz, C. (2000). The interpretation of cultures. 1973. New York: Basic.

Hayat, H., \& Zamzami, A. (2019). Mewujudkan New Public Management Terhadap Indisipliner Mahasiswa Melalui Penerapan AbCD (Absen Cap Driji). JIPEMAS: Jurnal Inovasi Hasil Pengabdian Masyarakat, 2(1). https://doi.org/10.33474/jipemas.v2i1.1613

Ismail, I., \& Elihami, E. (2019). Pelatihan Penyusunan Artikel Publikasi Ilmiah bagi Mahasiswa Perguruan Tinggi STKIP Muhammadiyah Enrekang. Maspul Journal of Community Empowerment, 1(1).

Kusumawardhani, R., Andris s, D., Prastikawati, E. F., \& Setyorini, A. (2012). Pelatihan Penulisan Artikel Ilmiah Guru Bahasa Inggris SMA di Kota Semarang (Sebagai Pencapaian KEPMENPAN Nomor 16 Tahun 2009 tentang Jabatan Fungsional Guru Dan Angka Kreditnya). E-DIMAS, 3(2). https://doi.org/10.26877/e-dimas.v3i2.364

Lieberman, L., \& Lewis, O. (1970). A Death in the Sanchez Family. American Sociological Review, 35(4). https:/ / doi.org/10.2307/2093995

Lund, C. (2014). Of what is this a case?: Analytical movements in qualitative social science research. Human Organization, 73(3). https://doi.org/10.17730/humo.73.3.e35q482014x03314

Mopangga, H. (2014). Faktor Determinan Minat Wirausaha Mahasiswa Fakultas Ekonomi dan Bisnis Universitas Negeri Gorontalo. TRIKONOMIKA, 13(1). https:// doi.org/10.23969/trikonomika.v13i1.486

Patton, M. Q. (2009). Metode Evaluasi Kualitatif. Pustaka Pelajar.

Popper, K. (2005). The logic of scientific discovery. In The Logic of Scientific Discovery. Routledge. https:/ / doi.org/10.4324/9780203994627

Pratama, M. R. (2017). Ketimpangan Pelayanan Publik. Republika.

Purwahida, Rahmah, Pratiwi, Dini Restiyanti, \& Arum, Dini Isnina. (2009). Pelatihan Penulisan Ilmiah Populer Bagi Guru SMK Muhammadiyah SeSurakarta. Jurnal Warta, 12 (2).

Salam, R., Akhyar, M., Tayeb, A. M., \& Niswaty, R. (2017). Peningkatan Kualitas Publikasi Ilmiah Mahasiswa dalam Menunjang Daya Saing Perguruan Tinggi. Jurnal Office, 3(1). https:// doi.org/10.26858/jo.v3i1.3463

P. D. Sasongko, Y. ., \& Hidayatul R., T. . (2021). Peningkatan Kemampuan Budaya Menulis Populer Pada Peserta Didik Dan Khalayak Umum Dalam Pengabdian Masyarakat Di Universitas Trunojoyo - Madura. Prosiding Penelitian Pendidikan Dan Pengabdian 2021, 1(1), 1099-1108.

Sugiarti, Anggraini, P., \& Musaffak. (2015). IbM Karya Tulis Ilmiah (KTI) Guru SMP Muhammadiyah 8 Batu.

Sword, H. (2012). Stylish Academic Writing. In Stylish Academic Writing. Harvard University Press. https://doi.org/10.4159/harvard.9780674065093

Tumanggor, Raja Oloan. (2014). Manfaat Pelatihan Menulis Karya Ilmiah Bagi Mahasiswa Sekolah Tinggi Teologi (STT) Cipanas, Cianjur, Jawa Barat. Prosiding Seminar Nasional Hasil Penerapan Penelitian \& Pengabdian Pada Masyarakat, 1 (1), 110-114. 
Uco, U. (2015). How to Write a Thesis. MIT Press.

Whitaker, A. (2010). Academic Writing Guide: A Step-by-Step Guide to Writing Academic Papers. University of Seattle. www.vsm.sk/Curriculum/academicsupport/academicwritingguide/p df 